\title{
Interstitial filmmaking, spatial displacement and quasi-family ties in Postcards from the Zoo (2012)
}

\section{Miaw Lee Teo}

To cite this article: Miaw Lee Teo (2021): Interstitial filmmaking, spatial displacement and quasi-family ties in Postcards from the Zoo (2012), Journal of Chinese Cinemas, DOI: 10.1080/17508061.2021.1926155

To link to this article: https://doi.org/10.1080/17508061.2021.1926155

\section{Published online: 21 May 2021.}

Submit your article to this journal $\sqsubset$

Q View related articles ¿

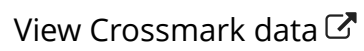




\title{
Interstitial filmmaking, spatial displacement and quasi- family ties in Postcards from the Zoo (2012)
}

\author{
Miaw Lee Teo \\ Faculty of Applied and Creative Arts, Universiti Malaysia Sarawak, Sarawak, Malaysia
}

\begin{abstract}
This article examines Chinese Indonesian filmmaker, Edwin's feature film, Postcards from the Zoo (2012). The lifting of the media regulations and the resurgence of Chinese identity in the reformasi era, a period after the downfall of Suharto's government (1966-1998), transformed the filmmaking scene in Indonesia. A young Chinese Indonesian filmmaker, Edwin emerged to take part in independent filmmaking. This article takes into consideration the filmmaker's ethnic Chinese background and the complexity of his hybrid identity and sense of in-betweenness, which plays an important role in structuring his cinematic practice. Through a close textual analysis of the film, the article interrogates the questions of spatial displacement and the potential of forging quasi-family ties that are not based on ethnic or racial identity. The discussion also focuses on the interstitial mode of production that evidenced through the multiple funding sources received by the film and the various roles the filmmaker plays in the productions. The film, Postcards from the Zoo (2012) shows Edwin works within an interstitial mode of production and, more specifically, the adoption of, what Hamid Naficy has called, "chronotopes of imagined homeland". This article provides a more in-depth examination of the concept in an attempt to analyse the notion of spatial displacement and interstitiality in Edwin's filmmaking.
\end{abstract}

\section{KEYWORDS}

Interstitial filmmaking; spatial displacement; interstitial mode of production;

Chineseness;

Chinese Indonesian Films;

film analysis

\section{Introduction}

The year 1998 ushered in an economic recession that devastated many Asian economies and saw anti-Chinese sentiment and discrimination in Indonesia reach its peak. The resulting outbreaks of violence not only caused the deaths of hundreds of Indonesian Chinese, but also triggered the downfall of Suharto's government and the dismantling of the New Order (1966-1998) (Purdey 2006; Coppel 2008). After decades of suppression by successive regimes, ethnic Chinese public expression experienced a revival in the period of political reformation, the reformasi (Allen 2003; Hoon 2006). Krishna Sen (2006), in her article "'Chinese' Indonesian in National Cinema", contends that Indonesian cinematic history, especially the history that is written by pribumi writers, is marked by a tendency to obscure 